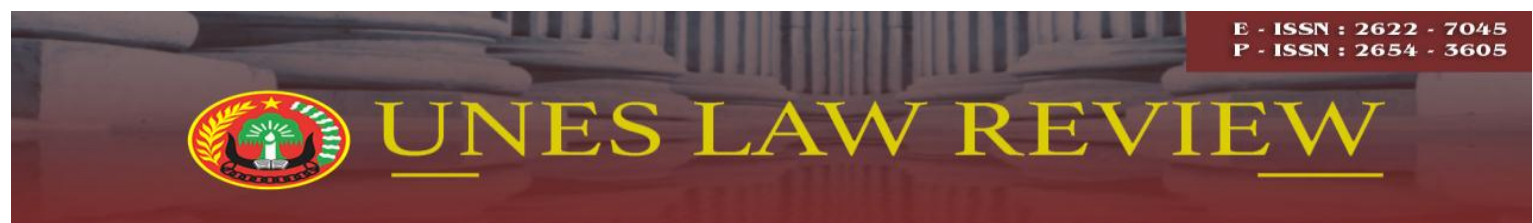

Email: uneslawreview@gmail.com

Online: http://review-unes.com/index.php/law

Volume 2, Issue 3, Maret 2020

\title{
PENERAPAN UNSUR PERMUFAKATAN JAHAT PADA PENYIDIKAN TINDAK PIDANA NARKOTIKA (Studi Pada Satres Narkoba Polresta Padang)
}

\author{
Herit Syah \\ Program Magister Ilmu Hukum, Universitas Ekasakti, Padang, Indonesia \\ Email : heritsyah559@gmail.com
}

\begin{abstract}
Bad conspiracy in Law Number 35 Year 2009 concerning Narcotics can be seen in Article 1 number 18 and Article 132 Paragraph (1) Investigation of conspiracy in narcotics crime requires evidence that shows an agreement. This research is a legal research with analytical descriptive specifications. The application of the element of bad consensus in the investigation of narcotics crime by investigators of the Padang Police Narcotics Investigation is to collect evidence so that it meets the elements of the existence of a trial / consensus, to commit narcotics crime as in the case with Police Report No. Pol: LP / 17 / IX / A / 2019 / Ta, October 27, 2018. Obstacles and Efforts to Overcome It in the Application of Criminal Consensus Elements in Narcotics Crimes by Investigators at the Narcotics of Padang Police Narcotics is the lack of equipment needed, the limited operational costs of the process investigation, it is difficult to get informants / espionage.
\end{abstract}

Kata Kunci: Tindak Pidana Narkotika, Permufakatan Jahat, Penyidikan, Alat Bukti

\section{PENDAHULUAN}

Permufakatan jahat di dalam Undang-Undang Nomor 35 Tahun 2009 tentang Narkotika dapat dilihat di dalam Pasal 1 angka 18, yaitu Permufakatan Jahat adalah perbuatan 2 (dua) orang atau lebih yang bersekongkol atau bersepakat untuk melakukan, melaksanakan, membantu, turut serta melakukan, menyuruh, menganjurkan, memfasilitasi, memberi konsultasi, menjadi anggota suatu organisasi kejahatan Narkotika, atau mengorganisasikan suatu tindak pidana Narkotika.

Permufakatan jahat di dalam tindak pidana narkotika apabila di urutkan dari terbentuknya suatu permufakatan jahat, yaitu dimulai dari niat, adanya 2 (dua) orang kesepakatan atau bersekongkol, melakukan tindak pidana. Mengenai perbuatan untuk dapat dipertanggungjawabkan sebagai perbuatan jahat atau sebagai tindak pidana dalam hal ini apakah bentuknya permufakatan jahat merupakan dasar memperluas delik atau tatbestandaus denungs grund dipandang sebagai delik berdiri sendiri di samping delik 
pokok yang disematkan padanya seakan-akan delik telah dianggap selesai. Selanjut untuk dapat dibuktikan haruslah secara expressis verbis dicantumkan di dalam pasal undangundang bila tidak disebutkan, ia merupakan unsur diam-diam atau stilzwijgend element (Abidin Farid, \& Hamzah, 2006:25).

Di dalam prakteknya sendiri seringkali pelaku tindak pidana narkotika apabila tindak pidananya dilakukan oleh 2 (dua) atau lebih, maka Penyidik menggunakan unsur adanya kesepakatan atau persekongkolannya. Pembuktian permufakatan jahat pada dasarnya sudah dimulai sejak tahap penyelidikan perkara tindak pidana, ketika penyelidik mencari dan menemukan peristiwa pidana yang diduga sebagai tindak pidana guna dapat atau tidaknya dilakukan penyidikan. Pada tahap ini sudah terjadi pembuktian, dengan tindakan penyidik mencari barang bukti tujuannya membuat terang suatu tindak pidana atau menemukan tersangkanya. Secara konkrit dapatlah dikatakan bahwa pembuktian berawal dari proses penyidikan dan berakhir pada penjatuhan pidana (vonis) oleh hakim di depan persidangan (Saiful Bahri, 2009:27).

Berdasarkan rumusan permufakatan jahat dalam tindak pidana Narkotika karena sangat merugikan dan merupakan bahaya yang sangat besar bagi kehidupan manusia, masyarakat, bangsa, dan negara serta ketahanan nasional Indonesia. Sudah sepantasnya permufakatan jahat dimasukkan dalam Undang-Undangan Nomor 35 Tahun 2009 tentang Narakotika mengingat dampaknya terhadap terhadap negara.

Berdasarkan latar belakang pemikiran di atas, maka permasalahan adalah Bagaimanakah penerapan unsur permufakatan jahat pada tindak pidana narkotika oleh penyidik pada Satres narkoba Polresta Padang dan Apakah kendala dan upaya mengatasinya dalam penerapan unsur permufakatan jahat pada tindak pidana narkotika oleh penyidik Satres narkoba Polresta Padang?

\section{METODE PENELITIAN}

Spesifikasi penelitian adalah deskriptif analitis, dengan metode pendekatan yuridis normative didukung oleh yuridis empiris. Jenis data yang digunakan adalah data sekunder. Data sekunder diperoleh dari studi dokumen dan studi kepustakaan. Data yang diperoleh kemudian dianalisa secara kualitatif. 


\section{HASIL PENELITIAN DAN PEMBAHASAN}

\section{Penerapan Unsur Permufakatan Jahat Pada Tindak Pidana Narkotika Oleh Penyidik Pada Satres Narkoba Polresta Padang}

Permufakatan jahat sebagaimana dimaksud dalam ketentuan Pasal 132 ayat (1) Undang-Undang Nomor 35 Tahun 2009 Tentang Narkotika bersifat ekseptional, yang artinya dianggap sebagai kejahatan pada tindak pidana yang disebutkan dalam UndangUndang Nomor 35 Tahun 2009 Tentang Narkotika, yakni pasal 111 sampai dengan pasal 126 dan pasal 129 dan kejahatan permufakatan jahat-pun dihukum sama dengan kejahatan pasal-pasal 111 sampai dengan pasal 126 dan Pasal 129 tersebut.

Permufakatan jahat/ samenspanning merupakan suatu kejahatan untuk melakukan suatu kejahatan, dapat dikatakan tindak pidana yang disepakati, dipersiapkan atau direncanakan tersebut belum terjadi. Dalam KUHP, percobaan dan permufakatan jahat hanya dihukum lebih ringan dari hukuman pokok. Namun berbeda dengan UndangUndang Nomor 35 Tahun 2009 Tentang Narkotika yang pada saat ini yang menghukum sama dengan hukuman pokok pada delik selesai. Dikarenakan Kejahatan Narkotika dipandang telah menjadi kejahatan serius.

Sebelum masuk pada pokok pembahasan penulis akan memberikan pengertian mengenai deelneming terlebih dahulu sebagai diatur dalam pasal 55 dan pasal $56 \mathrm{KUH}$ Pidana, menurut Satochid Kartanegara mengartikan deelneming yaitu apabila dalam satu delik tersangkut beberapa orang atau lebih dari satu orang (P.A.F Lamintang, 1984:23). Deelneming sendiri terdiri dari beberapa jenis, yaitu "orang yang melakukan (pleger atau dader), orang yang menyuruh melakukan (doen pleger), orang yang turut serta melakukan (medepleger), orang yang membujuk melakukan (uitlokker) dan orang yang membantu melakukan (medeplichtige).

Dalam praktik peradilan pidana saat ini, banyak penegak hukum menggunakan pasal 132 ayat (1) UU Narkotika untuk menjerat pelaku tindak pidana narkotika yang dilakukan oleh 2 orang atau lebih yang melakukan delik selesai (aflopende delic). Hal ini tentunya tidak sesuai dengan pengertian permufakatan jahat yang otentik sebagaimana pasal 1 angka 8 UU Narkotika. Alasan penggunaan pasal 132 ayat (1) UU Narkotika tersebut disandarkan pada alasan adanya asas lex specialis deorgat lex generalis, mengingat undang-undang narkotika merupakan lex specialis dari KUH Pidana. 
Munculnya pemikiran tersebut karena dalam pengertian permufakatan jahat dalam UU Narkotika terdapat frasa "melakukan, membantu, turut serta melakukan, menyuruh, menganjurkan” yang merupakan jenis deelneming sebagaimana diatur dalam pasal 55 dan pasal 56 KUH Pidana.

Pemikiran demikian kiranya kurang tepat, mengingat permufakatan jahat, baik yang diatur dalam UU Narkotika maupun KUH Pidana hanya di peruntukan terhadap tindak pidana yang tidak selesai (voorbereidingsdelicten), yaitu apabila terdapat dua orang atau lebih mereka telah bersepakat dan bersekongkol "untuk" melakukan tindak pidana narkotika, bukan ditujukan terhadap dua orang atau lebih yang telah melakukan tindak pidana narkotika yang selesai atau semua unsur sudah terpenuhi oleh fakta hukum (voltooid).

Pada penyidikan, aparat penegak hukum menerapkan Pasal 132 ayat (1) UndangUndang Narkotika untuk menjerat pelaku tindak pidana selesai yang dilakukan oleh 2 orang atau lebih. Hal ini tentunya, tidak sesuai dengan pengertian permufakatan jahat yang otentik. Karena permufakatan jahat yang didefinisikan Pasal 1 angka 18 Undang-Undang Narkotika dianggap sebagai Lex Specialist dari Pasal 55 Kitab Undang-Undang Hukum Pidana (KUHP). Pasal 1 angka 18 Undang-Undang Narkotika bukanlah Lex Specialist Pasal 55 Kitab Undang-Undang Hukum Pidana (KUHP), melainkan bijzondere deelneming dalam kejahatan Narkotika yang terorganisir, maka sebaiknya dalam perkara a quo, haruslah lebih cermat dalam menerapkan Pasal tersebut, sesuai fakta hukum agar kadilan dapat diterapkan dengan baik dan benar

Menuru Wirjono Prodjodikoro bijzondere deelneming yaitu sebagai keturut sertaan yang sifatnya khusus (A.R Sujono \& Bony Daniel, 2011:87). Sifatnya khusus karena permufakatan jahat tersebut memiliki kemiripan dengan deelneming dalam pasal 55 dan 56 KUH Pidana, akan tetapi lebih bersifat khusus. Perbedaannya bahwa keturutsertaan dalam Pasal 55 KUH Pidana para pelaku telah melakukan tindak pidana yang dilarang tersebut, sedangkan dalam permufakatan jahat tindak pidana belum dilakukan oleh pelaku. Jadi yang dihukum atau yang merupakan tindak pidana disini adalah niat yang ditandai adanya kata sepakat dan persekongkolan dari dua orang atau lebih untuk melakukan tindak pidana narkotika. 
Pengaturan bijzondere deelneming dalam tindak pidana narkotika cukup beralasan, sebagaimana telah dikemukakan di muka bahwa kejahatan narkotika merupakan serious crime, yang berdampak besar dan multi dimensional terhadap sosial, budaya, ekonomi dan politik serta begitu dahsyatnya dampak negatif bagi kelangsungan hidup umat manusia. Dengan mempertimbangkan teori hukum tentang delik-delik persiapan (voorbereidingsdelicten), pengertian secara otentik pasal 1 ayat (1) UU Narkotika, permufakatan jahat dalam pasal 132 ayat (1) UU Narkotika merupakan bijzondere deelneming dari pasal 55 dan 56 KUH Pidana bukan merupakan lex specialis, sehingga pasal 132 ayat (1) KUH Pidana tidak bisa menegasikan keberadaan pasal 55 dan pasal 56 KUH Pidana. Pasal 132 ayat (1) UU Narkotika digunakan terhadap perkara tindak pidana narkotika yang tidak selesai, yaitu terhadap dua orang atau lebih yang bersepakat atau bersengkongkol "untuk" melakukan tindak pidana narkotika, yang dihukum adalah niat yang ditandai adanya kata sepakat untuk melakukan kejahatan. Biasanya, pasal ini diterapkan terhadap kejahatan narkotika yang terorganisir. Sedangkan bagi tindak pidana narkotika yang selesai (voltooid) yang dilakukan dua orang atau lebih haruslah digunakan pasal 55 dan pasal 56 KUH Pidana, karena pasal 132 ayat (1) UU Narkotika tidak ditujukan untuk tindak pidana selesai, maka berlakulah ketentuan pasal 103 KUH Pidana yang merumuskan "Ketentuan dalam Bab I sampai dengan Bab VIII buku ini berlaku bagi perbuatan-perbuatan yang oleh ketentuan perundang-undangan lainnya diancam dengan pidana, kecuali jika oleh ketentuan undang-undang ditentukan lain".

Pasal 132 ayat (1) Undang Undang Narkotika merupakan pengaturan khusus dari Pasal 169 KUHP dengan melakukan perluasan deelneming-nya (bijzondere deelneming) hal ini dikarenakan kejahatan narkotika semakin meningkat dan membahayakan ketahanan bangsa Indonesia.

Adapun Pasal 1 angka 18 UUN menyebutkan sebagai "Permufakatan jahat adalah perbuatan dua orang atau lebih yang bersekongkol atau bersepakat untuk melakukan, melaksanakan, membantu, turut serta melakukan, menyuruh, menganjurkan, memfasilitasi, memberi konsultasi, menjadi anggota suatu organisasi kejahatan narkotika, atau mengorganisasikan suatu tindak pidana narkotika," Secara sederhana dalam penanganan masalah hukum Narkotika, khususnya sebanyak tujuh belas (17) pasal berkenaan permufakatan jahat, maka unsure penting nya adalah, para pihak (sedikitnya 2 orang), 
adanya kesepakatan (minimal ada nya "kata sepakat") dan maksud/tujuan niat melakukan tindak pidana Narkotika. Jika salah satu unsur tersebut tidak dipenuhi maka potensi penerapan pasal tersebut bisa keliru ataupun lebih mengarah kepada junto pasal 55 atau 56 KUH-Pidana.

Seperti pada perkara Penerapan unsur permufakatan jahat dalam Pasal 132 ayat (1) Undang-undang Republik Indonesia Nomor 35 tahun 2009 tentang Narkotika berdasarkan Laporan Polisi No. Pol :LP/17/IX/A/2019/Ta, tanggal 27 Oktober 2018 tidak sesuai dengan normanya, dimana pembuktian unsur tersebut didasarkan kepada bunyi unsur Pasal 132 ayat (1) Undang-undang Republik Indonesia Nomor 35 Tahun 2009 tentang Narkotika yang tidak lengkap sehingga menyebabkan makna dari unsur permufakatan jahat sebagaimana dimaksud dalam Pasal 132 ayat (1) Undang-undang Republik Indonesia Nomor 35 Tahun 2009 tentang Narkotika berbeda dengan yang seharusnya. Penerapan Pasal 132 ayat (1) Undang-undang Republik Indonesia Nomor 35 Tahun 2009 tentang Narkotika yang tidak lengkap. Tindakan penyidik yang menghilangkan frasa "untuk melakukan" pada Pasal 132 ayat (1) Undang-undang Republik Indonesia Nomor 35 tahun 2009 sebagaimana yang dimaksud dalam uraian unsur pasal tersebut telah mangaburkan alat bukti yang terkumpul.

Frasa "untuk melakukan" yang menjadi satu kesatuan bunyi Pasal 132 ayat (1) UU RI Nomor 35 tahun 2009 tentang Narkotika menimbulkan akibat hukum yang lain, dimana percobaan atau permufakatan jahat seolah-olah hanya dapat ditempatkan pada delik yang selesai (voltooid delict) saja. Berdasarkan penyidikan yang dilakukan terungkap bahwa barang bukti narkotika jenis shabu-shabu yang ditemukan oleh polisi pada diri Novrizal dan Novrizal mengakui narkotika tersebut adalah miliknya dan bukan milik Roni. Keadaan ini menunjukkan bahwa delik memiliki, menyimpan, atau menguasai narkotika jenis shabu memang secara nyata sudah selesai, namun hanya terbukti pada diri Novrizal saja, sedangkan terhadap terdakwa Roni sebenarnya tidak bisa dimintai pertanggungjawaban terhadap delik memiliki, menyimpan atau menguasai narkotika jenis shabu tersebut.

Berdasarkan alat bukti yang ada terungkap dari keterangan saksi CP. dan saksi M. Dedi Syah putra dan dikaitkan dengan barang bukti, para tersangka ditangkap oleh pihak Kepolisian karena kedapatan memiliki dan menguasai 1 (satu) plastik bening berisi Kristal berwarna putih dengan berat netto 0,68 (nol koma enam delapan) gram dan 3 (tiga) set alat 
bong (alat hisap narkotika jenis shabu), 4 (empat) buah mancis dan 5 (lima) buah sendok terbuat dari pipet, dimana sebelum para tersangka ditangkap para tersangka bekerja sama dimana tersangka Novrizal menyediakan narkotika jenis shabu untuk dijual kepada orang lain dan Roni menyediakan alat berupa bong untuk menggunakan narkotika jenis shabu tersebut kepada para pembeli, sehingga unsur ini sudah terpenuhi. Dengan demikian unsur percobaan atau permufakatan jahat telah terpenuhi.

\section{Kendala Dan Upaya Mengatasinya Dalam Penerapan Unsur Permufakatan Jahat Pada Tindak Pidana Narkotika Oleh Penyidik Pada Satres Narkoba Polresta Padang}

Adapun hambatan-hambatan dalam penyidikan dengan menerapkan unsur pemufakatan jahat, adalah Kurangnya jumlah peralatan yang diperlukan. Kekurangan peralatan yang digunakan untuk melakukan penyelidikan maupun penyidikan dalam hal ini adalah untuk melakukan penyadapan. Tanpa adanya peralatan yang cukup maka dapat mempengaruhi kecepatan serta ketelitian penyidik dalam mengumpulkan alat bukti mengenai suatu tindak pidana narkotika. Contohnya dalam melakukan pembelian terselubung penyidik mengaku mengalami kesulitan dalam melakukan penyadapan yang nantinya akan berguna sebagai alat bukti mengingat bahwa alat bukti yang digunakan dalam mengungkap serta menangani tindak pidana narkotika yang menyatakan bahwa segala bentuk informasi elektronik maupun data rekaman atau informasi yang bisa di lihat maupun Didengar maka akan bisa dijadikan alat bukti yang sah dalam persidangan untuk itu diperlukan penyadapan. Penyadapan dilakukan untuk mengetahui adanya kerjasama atau terpenuhinya untuk pemufakatan jahat dalam tindak pidana narkotika.

Terbatasnya biaya operasional proses penyidikan kasus narkotika dengan bersama sama memerlukan biaya operasional yang cukup tinggi jika dibandingkan dengan penyidikan dalam kejahatan konvensional. Jika penyidikan dalam kejahatan konvensional hanya membutuhkan biaya kurang lebih sekitar 500.000 rupiah sampai dengan 1.000.000 rupiah, lain halnya dalam penyidikan narkotika yang membutuhkan biaya operasional lebih dari 1juta rupiah. Kisaran mengenai biaya operasional tersebut tergolong relatif besar atau rata-rata biaya yang dibutuhkan antara 2.000.000 sampai dengan 3.000.000 mengingat biaya tersebut juga meliputi biaya transportasi, biaya dalam melakukan tehnik pembelian terselubung (under cover buy). 
Penyidik mendapatkan teror ketika menyamar walaupun sudah merubah penampilan misalnya dengan memakai anting, tato, dan berambut gondrong para anggota kepolisian tersebut lebih banyak dikenali dengan mudah oleh jaringan narkotika tersebut karena setiap anggota kepolisian tersebut, setiap setelah menangkap maka otomatis anggota tersebut akan menjadi saksi dalam pemeriksaan.

Di pemeriksaan seorang saksi tidak mungkin orang lain seorang saksi harus yang mengetahui tentang penangkapan itu, dan itu adalah anggota polisi sendiri Oleh karena itu anggota kepolisian penyidik narkoba yang sudah pernah melakukan penyamaran akan dengan mudah terdeteksi oleh teman anggota kelompok tersangka yang merupakan sebuah jaringan. Salah satu anggota jaringan tersebut biasanya hadir dan berbaur dimasyarakat untuk hadir dalam persidangan temanya yang sudah tertangkap sehingga para anggota polisi yang menjadi saksi dalam persidangan tersebut akan terdeteksi dan apabila akan melakukan penyamaran kembali akan mengalami kesulitan. Anggota penyidik kepolisian itu selain sudah terdeteksi oleh jaringan tersebut para anggota itu juga menjadi incaran bagi kelompok jaringan itu, karena bagi suatu jaringan narkoba mereka tidak mau untuk kalah dari kepolisian. Setelah salah satu rekan jaringan tersebut tertangkap, setidaknya polisi yang berhasil menangkap rekannya tersebut juga harus terkena suatu masalah.

Kendala dalam mendapatkan informan/spionase Informan sendiri adalah orang yang memiliki informasi tentang suatu subyek yang ingin diketahui, dalam hal ini informan adalah yang berkaitan tentang tindak kejahatan narkotika. Informan ini orang yang dapat memberikan penjelasan yang detail, dan akurat menyangkut apa, siapa, dimana, kapan, bagaimana dan mengapa, dalam suatu kasus tindak pidana narkotika. Informan dalam mengungkap tindak pidana narkotika menempati kedudukan yang sangat penting, oleh karena itu polisi dalam mendapatkan informan ini sangat kesulitan. Sesuai dengan namanya, dia adalah sumber informasi bagi polisi dalam mengungkap kasus narkoba. Tugas seorang informan sendiri adalah sebagai perantara polisi dalam mengungkap kasus narkotika. Informan ini adalah orang umum atau bukan merupakan anggota kepolisian. Dalam beberapa hal seorang informan ini adalah orang yang memiliki peran dalam suatu jaringan tersebut, sehingga kepolisian bisa dengan mudah mendapatkan informasi tentang jaringan itu apabila sudah memiliki seorang informan. 
Upaya yang dilakukan Untuk Mengatasi Hambatan dalam Pelaksanaan penyidikan Tindak Pidana Narkotika di Wilayah Hukum Kepolisian Resor Kota Padang dengan membangun fasilitas yang menunjang kinerja aparat kepolisian seperti Laboratorium, menambah personil, meningkatkan kedisiplinan dan perbaikan kinerja para anggota kepolisian dan saling berkordinasi sesama anggota dalam pemberantasan peredaran dan penyalahgunaan tindak pidana narkotika, serta memberikan keyakinan dan perlindungan hukum oleh polisi kepada saksi-saksi pelapor.

Mengenai konsepsi "kesepakatan" untuk melakukan tindak pidana, menurut Eddy OS Hiariej, adanya meeting of mind yang tidak mengharuskan adanya kesepakatan antara pelaku utama dengan penyerta. Adanya kesepakatan dua orang atau lebih untuk melakukan sesuatu kiranya sudah cukup kuat untuk menunjukan terpenuhinya unsur pemufakatan jahat. Ditegaskan pula bahwa meeting of mind tidak perlu dengan kata-kata yang menandakan persetujuan secara eksplisit akan tetapi cukup dengan bahasa tubuh dan kalimat-kalimat yang secara tidak langsung menandakan adanya kesepakatan. Adapun dasar pemikiran yang digunakan adalah Pasal 55 KUHP. Selain itu. Dalam teori hukum pidana dikenal dengan istilah sukzessive mittaterscraft yang berarti adanya keikutsertaan dalam suatu kejahatan termasuk permufakatan jahat dapat dilakukan secara diam-diam.

\section{PENUTUP}

Penerapan unsur permufakatan jahat pada penyidikan tindak pidana narkotika oleh penyidik Satres Narkoba Polresta Padang adalah dengan mengumpulkan alat bukti sehingga memenuhi unsur unsur adanya Percobaan/permufakatan jahat, untuk melakukan tindak pidana narkotika seperti pada perkara dengan Laporan Polisi No. Pol :LP/17/IX/A/2019/Ta, tanggal 27 Oktober 2018. Kedua; Kendala Dan Upaya Mengatasinya Dalam Penerapan Unsur Permufakatan Jahat Pada Tindak Pidana Narkotika Oleh Penyidik Pada Satres Narkoba Polresta Padang adalah kurangnya jumlah peralatan yang diperlukan, terbatasnya biaya operasional proses penyidikan, sulit mendapatkan informan/spionase. 


\section{DAFTAR PUSTAKA}

\section{Buku Taks:}

A.R Sujono \& Bony Daniel, Komentar dan Pembahasan Undang-Undang Nomor 35 Tahun 2009 tentang Narkotika, Sinar Grafika, Jakarta, 2011

P.A.F Lamintang, Dasar-Dasar Hukum Pidana, Citra Aditya, Bandung, 1984

Saiful Bahri, Hukum Pembuktian dalam Praktik Peradilan Pidana, Total Media, Yogyakarta, 2009.

Zainal Abidin Farid, A. Hamzah, Bentuk-Bentuk Khusus Perwujudan Delik (Percobaan, Penyertaan, dan Gabungan Delik) dan Hukum Penitensier, PT Raja Grafindo Persada, Jakarta, 2006.

\section{Peraturan Perundang-Undangan:}

Kitab Undang-Undang Hukum Pidana

Undang-Undang Nomor 35 Tahun 2009 tentang Narkotika

\section{Web, Hasil Penelitian \& Journal:}

Luthvi Febryka Nola, Permufakatan Jahat dalam Tindak Pidana narkotika, Jurnal ilmiah Living Law, Vol. VII, No. 24/II/P3DI/Desember/2015, Universitas Djuanda, Surabaya 